\title{
David Oliver: Let's not forget care homes when covid-19 is over
}

\author{
David Oliver consultant in geriatrics and general medicine
}

Berkshire

Care homes have been very badly hit by the covid-19 pandemic. This has highlighted their historical neglect and marginalisation and has belatedly brought them into the spotlight. We should not forget the lessons.

By mid-April, the government was being criticised for reporting only in-hospital deaths from covid-19 and not those from the wider community. ${ }^{1}$ By 22 April, the Office for National Statistics reported 1000 care home deaths from coronavirus in the previous five days. ${ }^{2}$

Media stories of unprotected and overwhelmed care home staff have mounted, as have the numbers of untested residents dying. Distraught relatives of residents have described their upset at being unable to visit loved ones. Bosses of large care home provider chains have described coronavirus outbreaks in a third or more of their homes. ${ }^{34}$

The healthcare business consultancy LaingBuisson says that around 410000 people aged over 65 live in the UK's 11300 nursing and residential homes. ${ }^{5}$ This outnumbers adult hospital beds by around three to one. Yet, before the pandemic, care homes were far less prominent in the media or the public consciousness than acute hospitals or GP surgeries, save for debates over social care funding or some high profile stories of neglectful care. Right now, care homes are on the front line of the pandemic as much as the NHS.

\section{Bewildered and depressed}

The Coronavirus $\mathrm{Act}^{6}$ and additional funding and permissions have enabled more homes to take in more residents from hospitals far sooner and to use any spare capacity, but often with no more staff. Care homes have been taking patients straight back from hospital wards at speed, covid-19 or not.

At the best of times, residents have complications and die from acute illness such as viral infections. ${ }^{7}$ Their survival rate from resuscitation is vanishingly low. ${ }^{8}$ When they're taken to hospital in blue light ambulances the experience is often distressing and bewildering, and around one in three dies there. ${ }^{9}$ It's always been right and proper to do more advance care planning for residents, document more decisions on resuscitation, and help support more residents in staying put unless they really need to go to hospital. The pandemic has not changed that reality.

Covid-19 has meant that many residents have to isolate in their own rooms and avoid communal areas. Already overstretched teams must now carry out all checks, assistance, and supervision within the rooms. There are no visiting relatives to provide companionship, reassurance, or help to relieve the strain. Residents deprived of usual interaction with family and friends can become bewildered and depressed.

\section{Fearful teams}

I've spoken to a number of people working with the care home sector, and I personally look after many patients admitted from care homes or leaving hospital for them. Managers are working long hours, combining their usual role with hands-on care to plug gaps. Staff are going off sick or are self-isolating because of sickness in their own families, and agency staff may be reluctant to work in homes full of positive cases.

Care homes still lack appropriate personal protective equipment for their staff. ${ }^{10}$ Fearful teams don't make for good morale despite their selfless efforts to care for residents they know and cherish. It's been very hard to test residents for covid-19 so far. Meanwhile, many homes now have on site far more acutely ill residents who would normally have been conveyed to hospital, which is putting further strain on care homes-not least those that don't employ registered nurses or don't have quick access to general practice, district nursing, or geriatrician support. And, if residents are dying and need end-of-life care or are breathless and need oxygen, there can be problems sourcing medicines, skilled palliative care support, or masks and cylinders.

The current crisis has brought into sharp focus issues around funding, staffing, and support for care homes that we should have tackled many years ago. Let's not forget this when the crisis is over.

Competing interests: See www.bmj.com/about-bmj/freelance-contributors. Provenance and peer review: Commissioned; not externally peer reviewed. 
1 Booth R. Hundreds of UK care home deaths not added to official coronavirus toll. Guardian 2020 Apr 9. https://www.theguardian.com/world/2020/apr/09/covid-19-hundreds-of-ukcare-home-deaths-not-added-to-official-toll.

2 Lay K, Calver T. UK care home deaths double in four weeks. Times 2020 Apr 22. https:/ /www.thetimes.co.uk/article/uk-care-home-deaths-double-in-four-weeks-7hjwb2bxf. (Login needed.)

3 Crawford A. Coronavirus: Care home boss expects his COVID-19 cases to almost double to 4500 in weeks. Sky News 2020 Apr 15. https://news.sky.com/story/coronavirus-carehome-boss-expects-his-covid-19-cases-to-almost-double-to-4-500-in-weeks-11973419.

4 National Care Forum. Ring of steel needed to support care homes as deaths double in a week. 18 Apr 2020. https://www.nationalcareforum.org.uk/ncf-press-releases/ring-ofsteel-needed-to-support-care-homes-as-deaths-double-in-a-week/.

5 Oliver D. David Oliver: A troubled care home market should concern us all. BMJ Opinion 2020 Mar 4. https://blogs.bmj.com/bmi/2020/03/04/david-oliver-troubled-care-home-marketshould-concern-us-all.

6 Coronavirus Act 2020. 2020. http://www.legislation.gov.uk/ukpga/2020/7/contents/enacted.
7 Oliver D. David Oliver: Reducing emergency admissions from care homes. BMJ 2019;367:l6149. 10.1136/bmj.l6149 31666225

8 Pape M, Rajan S, Hansen SM, etal . Survival after out-of-hospital cardiac arrest in nursing homes - A nationwide study. Resuscitation 2018;125:90-8.

10.1016/j.resuscitation.2018.02.004. 29425977

9 Dwyer R, Gabbe B, Stoelwinder JU, Lowthian J. A systematic review of outcomes following emergency transfer to hospital for residents of aged care facilities. Age Ageing 2014:43:759-66. http://ageing.oxfordjournals.org/content/early/2014/10/09/ageing.afu117. full. 10.1093/ageing/afu117 25315230

10 Cecil N. Damning warning from social care bosses over lack of PPE. Evening Standard 2020 Apr 16. https://www.standard.co.uk/news/health/social-care-bosses-warning-lackof-ppe-a4416006.html.

Published by the BMJ Publishing Group Limited. For permission to use (where not already granted under a licence) please go to http://group.bmj.com/group/rights-licensing/ permissions 